Acta Agroph., 2019, 26(1), 57-65

doi: $10.31545 /$ aagr/109050

\title{
EFFECT OF SELECTED BIOSTIMULANTS ON THE YIELD AND QUALITY OF THE COMMON ONION (ALLIUM CEPA L.)
}

\author{
Emilia Mikulewicz ${ }^{1} \mathbb{(}$, Joanna Majkowska-Gadomska ${ }^{1}$, \\ Krzysztof Konrad Jadwisieńczak ${ }^{2} \mathbb{0}$, Anna Francke ${ }^{1}[$ \\ ${ }^{1}$ Department of Horticulture, University of Warmia and Mazury in Olsztyn \\ ${ }^{2}$ Department of Heavy Duty Machines and Research Methodology, University of Warmia and Mazury \\ Prawocheńskiego 21, 10-957, Olsztyn, Poland \\ e-mail: emilia.mikulewicz@uwm.edu.pl
}

Abstract. A field experiment was conducted in 2017-2018 in the Agricultural Experiment Station owned by the University of Warmia and Mazury in Olsztyn. The experiment had a randomized block design with three replications. The first experimental factor was a number of common onion cultivars: 'Whitney Wing F1', 'Spirit F1' and 'Red Baron'. The second experimental factor was the effect of two plant growth biostimulants; Calleaf Aminovital and Maximus Amino Protect, on the yield and quality of the onions. In the control treatment, plots were sprayed with water. The total yield, marketable yield and the marketable yield as a percentage of the total yield, the weight, vertical diameter and horizontal diameter of each onion bulb, the content of dry matter, total sugars, reducing sugars, L-ascorbic acid and nitrates (V) in the onions were determined in the study. The evaluated cultivars differed significantly with regard to the weight and size of the onions. Onions of cv. 'Whitney Wing F1' were characterized by a greater yield, and the weight, vertical diameter and horizontal diameter of the bulbs were all higher than they were for the remaining cultivars. The concentrations of dry matter, total sugars, L-ascorbic acid and nitrates (V) were higher in cv. 'Red Baron'. The contents of L-ascorbic acid and nitrates $(\mathrm{V})$ were significantly affected by the application of biostimulants, and the effects were more pronounced for onions treated with Maximus Amino Protect. The interaction between the experimental factors had a significant effect on the weight of individual onion bulbs, and on the concentrations of dry matter and L-ascorbic acid in the edible plant parts.

Ke y w ords: morphology, nutritional value, biostimulants, total yield, common onion

\section{INTRODUCTION}

The common onion (Allium cepa $\mathrm{L}$.) is one of the most widely cultivated bulb vegetable species. Onions have a high nutritional value, which may vary depending on the variety. The different properties and features of the onion varieties produced 
are a response to market demands and changing consumer requirements (Tendaj et al. 2014). Numerous studies have shown that the colour of fleshy and dry onion scales is correlated with both yield and nutrient and mineral content, which has important implications for the pharmaceutical and therapeutic uses of onion bulbs and their storability (Degewione et al. 2011).

The demand for organic foods is on the rise, and vegetable producers are expected to improve their cultivation technology with the use of biopreparations that increase crop yield and productivity, and improve crop quality (Czapski et al. 2009). Hallman and Rembiałkowska (2007b) demonstrated that organic foods contain lower amounts of harmful chemicals, including pesticide and fertilizer residues. According to the literature, biopreparations are effective in counteracting the adverse effects of environmental stressors such as salinity and heat. Many authors have emphasized the beneficial influence of organic farming on crop quality (Hamouz et al. 2005). In a study by Hallmann and Rembiałkowska (2007b), organically grown onions were shown to have a higher biological value than conventionally grown onions. Calleaf Aminovital and Maximus Amino Protect are liquid biofertilizers with bio-stimulatory and anti-stress properties. The free amino acids in both products contribute to protein synthesis, participate in enzymatic reactions in plants and stimulate their defence responses (Gugała et al. 2017).

The aim of this study was to determine the yield and morphological characteristics of the onions studied, as well as the content of selected nutrients in the bulbs of three onion cultivars grown with the use of biostimulants.

\section{MATERIALS AND METHODS}

A field experiment was conducted in 2017-2018 to determine the morphological traits and nutrient content of three common onion cultivars. The experiment, established in the Agricultural Experiment Station owned by the University of Warmia and Mazury in Olsztyn, had a randomized block design with three replications. The first experimental factor were a number of common onion cultivars: 'Whitney Wing $\mathrm{F}_{1}$ ' - with white dry and fleshy scales, 'Spirit $\mathrm{F}_{1}$ ' - with brown and straw-coloured dry scales and white fleshy scales, and 'Red Baron' - with red dry and fleshy scales. The second experimental factor was the effect of two plant growth biostimulants: Calleaf Aminovital and Maximus Amino Protect, applied at a dose of $0.3 \%$, on the yield, morphology and nutrient content of the onions. In the control treatment, the plots were sprayed with water. Each year, seeds were sown between the $10^{\text {th }}$ and $20^{\text {th }}$ of May, in $1 \mathrm{~m}^{2}$ plots, at $0.2 \times 0.2 \mathrm{~m}$ spacing. The mineral content of the control was analysed prior to establishing the experiment and the following results were obtained: $\mathrm{N}-\mathrm{NO}_{3}-38, \mathrm{P}-90, \mathrm{~K}-150, \mathrm{Ca}-184, \mathrm{Mg}-194\left(\mathrm{mg} \mathrm{dm}^{-3}\right)$. Due to the low nitrate nitrogen content of the soil, nitrogen was applied at a single dose 
of $200 \mathrm{~kg} \mathrm{ha}^{-1}$ in the form of ammonium saltpeter, 14 days before the onion seeds were sown. Soil tillage and agronomic treatments were consistent with the generally observed standards for common onions grown from seeds (www.piorin.gov. pl). The biostimulants were applied on three occasions, at 14-day intervals, beginning 2 weeks after seedling emergence. The local meteorological conditions were elaborated on the basis of data from the Meteorological Station in Tomaszkowo. In both study years, the temperature of the air during the growing season of the onions ranged from $5.7^{\circ} \mathrm{C}$ (April 2017) to $19.7^{\circ} \mathrm{C}$ (July 2018). The warmest month was August - average $18.4^{\circ} \mathrm{C}$. Atmospheric precipitation ranged from $1.8 \mathrm{~mm}$ (June 2018 ) to $59.4 \mathrm{~mm}$ (August 2017). The average atmospheric precipitation during the growing season of the onions was $29.6 \mathrm{~mm}$. The onions were harvested in the last 10 days of August. They were dried out, and shrivelled leaves were removed from the bulbs. The total yield, marketable yield and the marketable yield as a percentage of the total yield were estimated. Onion bulbs were sampled from the marketable yield in order to prepare average samples from each treatment. The onions of the evaluated cultivars were subjected to a morphological analysis and assayed for the content of selected chemical compounds. The weight, vertical diameter and horizontal diameter of the onion bulbs were determined. The chemical composition of the onions was analysed in the laboratory of the Department of Horticulture by determining the content of: dry matter - by drying the samples at $105^{\circ} \mathrm{C}$ to a constant weight (PN90/A-75101/03), total sugars and reducing sugars - as described by Luff-Schoorl (PN-90/A-75101/07), L-ascorbic acid - by the method proposed by Tillmans and modified by Pijanowski (Determination of vitamin $\mathrm{C}$ content... PN90/A-75101/11), and nitrates (V) - colorimetrically, with the use of salicylic acid.

The results were processed statistically using an analysis of variance (ANOVA) and Tukey's test at a significance level of $\alpha=0.05$, with the use of the STATISTICA 13 program.

\section{RESULTS AND DISCUSSION}

For the analysed onion cultivars, the average total yield was $252.06 \mathrm{~kg} 100 \mathrm{~m}^{-2}$, and the marketable yield reached $251.42 \mathrm{~kg} 100 \mathrm{~m}^{-2}$ (Tab. 1). The onion plants of cv. 'White Wing $F_{1}$ ' were characterized by a higher yield per unit area, relative to the other cultivars studied. The yield of onions of cv. 'Spirit $\mathrm{F}_{1}$ ' was significantly lower. Onion plants treated with Calleaf Aminovital were characterized by higher total and marketable yields. The interaction between the experimental factors contributed to higher total and marketable yields in onions of cv. 'White Wing $\mathrm{F}_{1}$ ' treated with Maximus Amino Protect. The percentage of the marketable yield as a percentage of the total yield varied across cultivars. For onion plants of cv. 'White Wing $F_{1}$ ' and 'Red Baron' treated with Amino Protect, the marketable yield 
accounted for $100 \%$ of total yield. For onion plants of cv. 'Spirit F1' in the control treatment, the marketable yield accounted for $99.04 \%$ of the total yield. In a previous study, Tendaj et al. (2014) found no significant differences between the yields of the evaluated onion cultivars, and the marketable yield ranged from 226.77 to $325.88 \mathrm{~kg} 100 \mathrm{~m}^{-2}$. Konopiński et al. (2006) analysed onions of cv. 'Wolska' and reported a total yield of 177.20 to $311.00 \mathrm{~kg} 100 \mathrm{~m}^{-2}$, and a marketable yield of 146.50 to $273.10 \mathrm{~kg} 100 \mathrm{~m}^{-2}$ depending on the production technology used.

Table 1. The effect of biostimulants on the total yield, marketable yield and the marketable yield as a percentage of the total yield of the common onion (Allium cepa L.) bulbs

\begin{tabular}{|c|c|c|c|c|}
\hline \multirow[t]{2}{*}{ Cultivar } & \multirow[t]{2}{*}{ Biostimulant } & $\begin{array}{l}\text { Total } \\
\text { yield }\end{array}$ & Marketable yield & \multirow{2}{*}{$\begin{array}{c}\text { Marketable yield as } \\
\text { a percentage of the total yield } \\
\%\end{array}$} \\
\hline & & \multicolumn{2}{|c|}{$\mathrm{kg} 100 \mathrm{~m}^{-2}$} & \\
\hline \multirow[t]{4}{*}{ 'White Wing F1' } & Control * & 302.8 & 301.7 & 99.63 \\
\hline & Calleaf Aminovital & 298.5 & 298.5 & 100.00 \\
\hline & Maximus Amino Protect & 315.2 & 315.0 & 99.93 \\
\hline & Mean & 305.5 & 305.1 & 99.85 \\
\hline \multirow[t]{4}{*}{ 'Spirit F1' } & Control & 178.2 & 176.5 & 99.04 \\
\hline & Calleaf Aminovital & 202.8 & 201.1 & 99.16 \\
\hline & Maximus Amino Protect & 198.4 & 197.6 & 99.59 \\
\hline & Mean & 193.1 & 191.7 & 99.30 \\
\hline \multirow[t]{4}{*}{ 'Red Baron' } & Control & 274.2 & 273.8 & 99.85 \\
\hline & Calleaf Aminovital & 265.9 & 265.9 & 100.00 \\
\hline & Maximus Amino Protect & 232.9 & 232.7 & 99.91 \\
\hline & Mean & 257.6 & 257.5 & 99.92 \\
\hline \multirow[t]{3}{*}{ Mean } & Control & 305.5 & 305.1 & 99.85 \\
\hline & Calleaf Aminovital & 306.4 & 306.2 & 99.93 \\
\hline & Maximus Amino Protect & 266.3 & 265.5 & 99.61 \\
\hline \multicolumn{5}{|l|}{$\mathrm{HSD}_{0,05}$ for: } \\
\hline biostimulant (b) & & n.s. $* *$ & n.s. & n.s. \\
\hline interaction (axb) & & n.s. & n.s. & n.s. \\
\hline
\end{tabular}

* Control - control treatment (without biostimulant); Calleaf Aminovital - Calleaf Aminovital applied on three occasions, at 14-day intervals during plant growth; Maximus Amino Protect - Maximus Amino Protect applied on three occasions, at 14-day intervals during plant growth; **n.s. - no significant difference

A statistical analysis revealed that the weight of the onion bulbs was the only morphological parameter significantly affected by the cultivar and the interaction between the experimental factors (Tab. 2). 'White Wing $\mathrm{F}_{1}$ ' was characterized by the highest average weight of a single bulb (198.6 g), the average weight of the onions of cv. 'Red Baron' was similar, whereas the onions of cv. 'Spirit $\mathrm{F}_{1}$ ' had a significantly lower average weight $(138.3 \mathrm{~g})$. An analysis of the experimental factors confirmed that the weight of onion bulbs was significantly higher for $\mathrm{cv}$. 'White Wing $F_{1}$ ' treated with Maximus Amino Protect and grown in the control treatment, and for cv. 'Red Baron' grown in the control treatment. A significantly 
lower onion weight was noted for $\mathrm{cv}$. 'Spirit $\mathrm{F}_{1}$ ' in all treatments, and for cv. 'Red Baron' treated with Maximus Amino Protect. The obtained values were higher than those reported by Majkowska-Gadomska et al. (2016), and comparable with those reported by Tendaj et al. (2014) and Wojciechowska and Kołton (2014) which ranged from 112 to $207 \mathrm{~g}$ depending on the cultivar.

Table 2. The effect of biostimulants on the morphology of the common onion (Allium cepa L.) bulbs

\begin{tabular}{llccc}
\hline \multirow{2}{*}{ Cultivar } & \multicolumn{1}{c}{ Biostimulant } & $\begin{array}{c}\text { Mass of } \\
\text { an individual } \\
\text { onion }\end{array}$ & $\begin{array}{c}\text { Vertical } \\
\text { diameter }\end{array}$ & Horizontal diameter \\
\cline { 2 - 4 } 'White Wing F1' & Control * & 194.7 & 70.2 & $\mathrm{~mm}$ \\
& Calleaf Aminovital & 177.5 & 63.8 & 73.7 \\
& Maximus Amino Protect & 223.7 & 69.9 & 69.7 \\
'Spirit F1' & Mean & 198.6 & 68.0 & 77.0 \\
& Control & 127.3 & 58.1 & 61.2 \\
& Calleaf Aminovital & 147.0 & 59.0 & 64.5 \\
'Red Baron' & Maximus Amino Protect & 140.6 & 54.7 & 62.4 \\
& Mean & 138.3 & 57.2 & 62.7 \\
& Control & 221.6 & 54.8 & 68.2 \\
Mean & Maximus Amino Protect & 182.0 & 56.3 & 71.7 \\
& Mean & 156.5 & 58.6 & 80.3 \\
& Control & 186.7 & 56.6 & 73.4 \\
HSD $\alpha_{0,05}$ for: & Calleaf Aminovital & 181.2 & 61.0 & 67.7 \\
cultivation (a) & Maximus Amino Protect & 168.8 & 59.7 & 68.6 \\
biostimulant (b) & & 173.6 & 61.1 & 73.2 \\
interaction(axb) & & & & \\
\hline
\end{tabular}

Explanations as in Table 1

Following the trend of the weight results, onions of cv. 'White Wing $\mathrm{F}_{1}$ ' were also characterized by higher vertical and horizontal diameters $(68.0$ and $73.5 \mathrm{~mm}$, respectively). Onions of cv. 'Red Baron' had a lower average vertical diameter $(56.6 \mathrm{~mm})$, and onions of $\mathrm{cv}$. 'Spirit $\mathrm{F}_{1}$ ' also had a lower average horizontal diameter $(62.7 \mathrm{~mm})$. However, the observed differences were not statistically significant. Similar values were noted by Majkowska-Gadomska et al. (2016) who investigated the growth rate of common onions.

According to Pudzianowska et al. (2012) and Hellman and Rembiałkowska (2007b), the dry matter content of onions is usually affected by the cultivar grown and by the applied preparations and products. Among the analysed cultivars, onions of cv. 'Red Baron' were characterized by a significantly higher dry matter content $(11.79 \%)$, which is associated with improved storage quality and a higher resistance to adverse environmental conditions during the growing season (Tendaj et al. 2014, Getahun et al. 2003). The Maximus Amino Protect biostimulant contributed 
to an increase in the dry matter content of the onion bulbs, but the differences noted were not statistically significant (Tab. 3). The interaction of cv. 'Red Baron' with all treatments led to an increase in the dry matter content of the onion bulbs, from 11.51 to $12.03 \%$. The onions of cv. 'White Wing $\mathrm{F}_{1}$ ' treated with Calleaf Aminovital contained significantly less dry matter $(6.72 \%)$. In experiments conducted by Hellman and Rembiałkowska (2007) and Tendaj et al. (2014), organically grown onions with red scales had a higher dry matter content than conventionally grown onions (9.78 to $13.63 \%$ on average). Similar results were reported by Badełek et al. (2016) - 11.1-13.7\%, Tendaj et al. (2014) - 8.20-9.78\%, and Wojciechowska and Kołton (2014) - 5.55-12.45\%.

Table 3. The content of selected nutrients, nitrates (V) and dry matter in common onions (Allium cepa L.) bulbs

\begin{tabular}{|c|c|c|c|c|c|c|}
\hline \multirow{2}{*}{ Cultivar } & \multirow{2}{*}{ Biostimulant } & $\begin{array}{c}\text { Dry } \\
\text { matter }\end{array}$ & $\begin{array}{c}\text { Total } \\
\text { sugars }\end{array}$ & $\begin{array}{c}\text { Reducing } \\
\text { sugars }\end{array}$ & $\begin{array}{c}\text { L-ascorbic } \\
\text { acid }\end{array}$ & Nitrates (V) \\
\hline & & $\%$ & \multicolumn{2}{|c|}{$\mathrm{g} 100 \mathrm{~g}^{-1} \mathrm{FW}$} & $\mathrm{mg} 100 \mathrm{~g}^{-1} \mathrm{FW}$ & $\begin{array}{l}\mathrm{N}-\mathrm{NO}_{3}^{-} \\
\mathrm{kg}^{-1} \mathrm{FW}\end{array}$ \\
\hline \multicolumn{2}{|c|}{ 'White Wing $\mathrm{F}_{1}$ ' Control } & 8.59 & 4.14 & 2.92 & 4.65 & 54.89 \\
\hline & Calleaf Aminovital & 6.72 & 4.52 & 2.68 & 5.41 & 51.26 \\
\hline & Maximus Amino Protect & 10.41 & 4.17 & 3.10 & 6.59 & 62.50 \\
\hline & Mean & 8.57 & 4.28 & 2.90 & 5.55 & 56.22 \\
\hline \multirow[t]{4}{*}{ 'Spirit $\mathrm{F}_{1}{ }^{\prime}$} & Control & 8.12 & 4.28 & 2.54 & 7.22 & 46.01 \\
\hline & Calleaf Aminovital & 9.47 & 3.92 & 2.63 & 3.39 & 67.65 \\
\hline & Maximus Amino Protect & 10.39 & 3.91 & 2.43 & 5.40 & 71.84 \\
\hline & Mean & 9.32 & 4.04 & 2.53 & 5.33 & 61.83 \\
\hline \multirow[t]{4}{*}{ 'Red Baron' } & Control & 12.03 & 5.11 & 2.83 & 7.00 & 61.41 \\
\hline & Calleaf Aminovital & 11.51 & 4.15 & 2.10 & 5.20 & 68.11 \\
\hline & Maximus Amino Protect & 11.82 & 4.16 & 2.33 & 8.40 & 66.21 \\
\hline & Mean & 11.79 & 4.47 & 2.42 & 6.86 & 65.24 \\
\hline \multirow[t]{3}{*}{ Mean } & Control & 9.58 & 4.51 & 2.76 & 6.29 & 54.10 \\
\hline & Calleaf Aminovital & 9.23 & 4.20 & 2.47 & 4.67 & 62.34 \\
\hline & Maximus Amino Protect & 10.87 & 4.08 & 2.62 & 6.79 & 66.85 \\
\hline \multicolumn{7}{|c|}{$\mathrm{HSD}_{0,05}$ for: } \\
\hline \multirow{3}{*}{\multicolumn{2}{|c|}{$\begin{array}{l}\text { cultivar (a) } \\
\text { biostimulant (b) }\end{array}$}} & 1.23 & n.s. & n.s. & n.s. & n.s. \\
\hline & & n.s. & n.s. & n.s. & 1.44 & 94.00 \\
\hline & interaction (axb) & 1.25 & n.s. & n.s. & 2.12 & n.s. \\
\hline
\end{tabular}

Explanations as in Table 1

The average content of total sugars in the onions of the evaluated cultivars

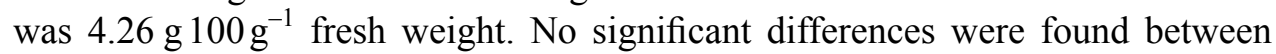
the experimental factors or their interactions. According to Matłok et al. (2014) and Jadczak and Wójcik-Stopczyńska (2007), the content of total sugars in onions is affected by environmental conditions during the growing season, and may vary across years. In the current study, the concentrations of total sugars in onion bulbs

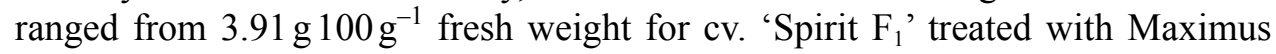


Amino Protect to $5.11 \mathrm{~g} 100 \mathrm{~g}^{-1}$ fresh weight for cv. 'Red Baron' grown in the control treatment. Our results are similar to those reported by Matłok et al. (2014) at

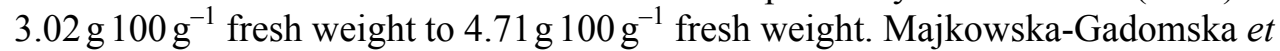

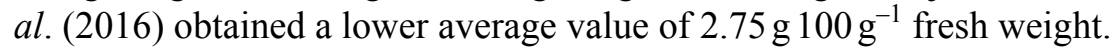

In an earlier study by Tendaj et al. (2014), the content of reducing sugars in onion

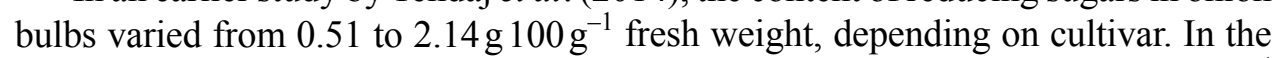
present experiment, the concentrations of reducing sugars ranged from $2.1{\mathrm{~g} 100 \mathrm{~g}^{-1}}^{-1}$ fresh weight for onions of cv. 'Red Baron' treated with Calleaf Aminovital to

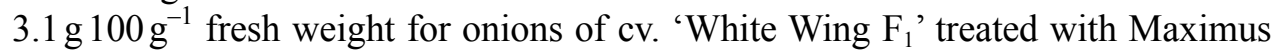
Aminovital Protect. The differences noted were not statistically significant.

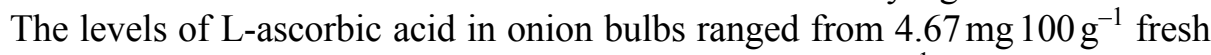

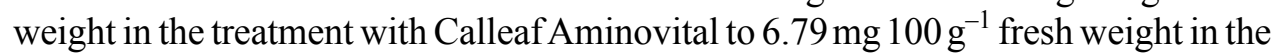
treatment with Maximus Amino Protect. An analysis of the interaction between the experimental factors revealed that onions of cv. 'Red Baron' treated with Maximus Amino Protect were characterized by a significantly higher content of L-ascorbic

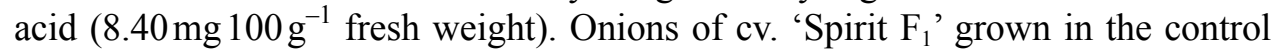
treatment also had a relatively high content of L-ascorbic acid. Significantly lower concentrations of L-ascorbic acid were noted for $\mathrm{cv}$. 'Spirit $\mathrm{F}_{1}$ ' treated with biostimulants, for cv. 'White Wing $\mathrm{F}_{1}$ ' treated with Calleaf Aminovital and grown in the control treatment, and for cv. 'Red Baron' treated with Calleaf Aminovital. Similar levels of L-ascorbic acid in onions were reported by Ashwini et al. (2013), in the

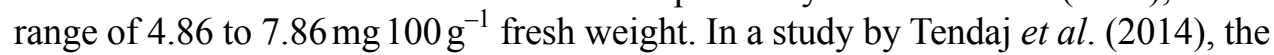

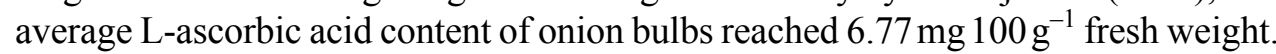
Hellmann and Rembiałkowska (2007b) demonstrated that the content of L-ascorbic acid in organically grown onions ranged from $26.50 \mathrm{mg} 100 \mathrm{~g}^{-1}$ fresh weight for $\mathrm{cv}$.

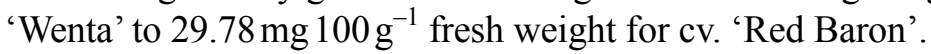

The cultivation method had a significant effect on the content of nitrates (V) in common onions. A higher content of nitrates (V) may indicate an improved nutritional status for the plants after the use of biostimulants. Onion bulbs treated with Maximus Aminovital Protect were characterized by a significantly higher average concentration of nitrates $(\mathrm{V})-66.85 \mathrm{mg} \mathrm{N}-\mathrm{NO}_{3}^{-} \mathrm{kg}^{-1}$ fresh weight, which dropped to $54.10 \mathrm{mg} \mathrm{N}^{-\mathrm{NO}^{-}}{ }_{3} \mathrm{~kg}^{-1}$ fresh weight on average in the control treatment. Different results were reported by Badałek et al. (2016) - 25.5 to $27.3 \mathrm{mg} \mathrm{N}-\mathrm{NO}_{3}^{-} \mathrm{kg}^{-1}$ fresh weight. In a study by Wojciechowska and Kolton (2014), nitrate (V) levels in common onions ranged from $73.4 \mathrm{mg} \mathrm{N}-\mathrm{NO}^{-}{ }_{3} \mathrm{~kg}^{-1}$ fresh weight for cv. 'Efekt' to $118.6 \mathrm{mg} \mathrm{N}^{-\mathrm{NO}^{-}}{ }_{3} \mathrm{~kg}^{-1}$ fresh weight for cv. 'Takstar $\mathrm{F}_{1}$ '. 


\section{CONCLUSIONS}

1. Onions of $\mathrm{cv}$. 'Whitney Wing $\mathrm{F}_{1}$ ' were characterized by a higher weight, vertical diameter and horizontal diameter of the bulbs than the other cultivars studied.

2. Onions of cv. 'Red Baron' with red dry and fleshy scales were characterized by higher concentrations of dry matter, total sugars, L-ascorbic acid and nitrates (V) than the other cultivars studied.

3. Onions treated with the Maximus Amino Protect biostimulant were characterized by a higher vertical diameter and horizontal diameter of the bulbs, and higher concentrations of dry matter, L-ascorbic acid and nitrates $(\mathrm{V})$ than onions treated with Calleaf Aminovital.

\section{REFERENCES}

Ashwini M., Balaganesh J., Balamurugan S., Murugan S.B., Sathishkumar R., 2013. Antioxidant Activity in Vivo and in Vitro Cultures of Onion Varieties (Bellary and $\mathrm{CO}_{3}$ ). Food Nutr. Sci., 4, 918-923, https://doi.org/10.4236/fns.2013.49119

Badałek E., Kosson R., Adamicki F., Maciorowski R., 2016. The effect of cultivar and storage conditions content of some ingredients in onion (in Polish). Zesz. Nauk. Inst. Ogrod., 24, 19-31.

Czapski J., Kidoń M., Olejnik A., Witrowa-Rajchert D., 2009. Purple carrot as raw material for processing industry (in Polish). Przem. Ferm. Owoc.-Warzywny, 5(1), 31-33.

Degewione A., Alamerew S., Tabor G., 2011. Genetic variability and association of bulb yield and related traits in shallot (Allium cepa var. aggregatum Don.) in Ethiopia. Int. J. Agric. Res., 6(7), 517-536, https://doi.org/10.3923/ijar.2011.517.536

Getahund D., Zelleke A., Derso E., Kiflu E., 2003. Storability of shallot cultivars (Allium cepa L. var. ascalonicum Backer). Acta Hortic., 604, 639-646, https://doi.org/10.17660/ActaHortic.2003.604.78

Gugała M., Sikorska A., Zarzecka K., Krasnodębska E., Kapela K., Mystkowska I., 2017. Profitability of application biostimulators in winter rape crop (in Polish). Roczniki Naukowe Stowarzyszenia Ekonomistów i Agrobiznesu, 19(4), 92-96.

Hallmann E., Rembiałkowska E., 2007b. Selected nutrient content in red onions from organic and conventional production (in Polish). Żywn. Nauka. Technol. Jakość, 2(51), 105-111.

Hamouz K., Lachman J., Dvořák P., Piviec V., 2005. The effect of ecological growing on the potatoes yield and quality. Plant Soil Environ., 51(9), 397-402, https://doi.org/10.17221/3603-PSE

Jadczak D., Wójcik-Stopczyńska B., 2007. Influence of plant covering on some organic compound content and pungency of shallot grown for bunching harvest (in Polish). Veg. Crops Res. Bull., 66, 25-30, https://doi.org/10.2478/v10032-007-0004-x

Konopiński E., Kęsik T., Błażewicz-Woźniak M., Mitura R., 2006. Effect of conservation tillage on plants emergence and yield of onion cultivar Wolska. Acta Agroph., 7(3), 611-618.

Majkowska-Gadomska J., Jadwisieńczak K., Dobrowolski A., Mikulewicz E., Janiak K., 2016. The growth rate and nutritional value of the common onion (in Polish). Acta Agroph., 23(1), 79-86.

Motłek N., Gorzelany J., Bilek M., Pieniążek R., Kuźniar P., Kaniuczak J., 2014. Sugar content in selected varieties of onion collected from the three plant breeding and seed production farms (in Polish). Zesz. Probl. Post. Nauk Roln., 576, 79-87. 
Pudzianowska M., Gajewski M., Przybył J.L., Buraczyńska A., Gaczkowska O., Matuszczak M., Dziechciarska M., 2012. Influence of storage conditions on flavonoids content and antioxidant activity of selected shallot (Allium cepa var. ascalonicum Backer) hybrid cultivars. Veg.Crops Res. Bull., 77, 101-111, https://doi.org/10.2478/v10032-012-0019-9

Tendaj M., Mysiak B., Gruszecki R., 2014. Yield and content of selected nutrient components in common onion and shallot cultivars (in Polish). Ann UMCS Sec EEE., 24(1), 1-8.

Wojciechowska R., Kołton A., 2014. Comparison of the ability of fifteen onion (Allium cepa L.) cultivars to accumulate nitrates (in Polish). Acta Agrobot., 67(1), 27-32, https://doi.org/10.5586/ aa.2014.006. 